\title{
THE EFFECT OF HEEL TYPE ON Q ANGLE
}

\section{Pruthini Patil ${ }^{1}$, Namrata Sidhaye- Bhadbhade ${ }^{* 2}$.}

${ }^{1}$ Intern at D.E.S Brijlal Jindal College of Physiotherapy, Jindal college of Physiotherapy, Fergusson college campus, Shivajinagar, Pune, Maharashtra, India.

${ }^{*}$ Assistant Professor at D.E.S Brijlal Jindal College of Physiotherapy, Jindal college of Physiotherapy, Fergusson college campus, Shivajinagar, Pune, Maharashtra, India.

\section{ABSTRACT}

Background: Around $80 \%$ of women prefer wearing high heel footwear, out of which $30 \%$ use it for professional reasons. Usage of high heel footwear revealed to exhibit pathological differences in entire lower limb mechanics.There is a dearth of literature regarding change in surface area of contact of footwear on lower limb biomechanics, with constant heel height in high heel footwear users.

Study design: Cross sectional observational study.

Objectives: To assess and compare $Q$ angle in women wearing flat heel, wedges and pointed heel footwear.

Methodology: 147 females were screened and only 99 (according to inclusion and exclusion criteria) were enrolled in the study. Three groups were made (33 participants in each group). Q angle measurements were taken in supine and standing positions. Collected data was analysed using one way ANOVA and Post Hoc analysis.

Results: Mean value of the $Q$ angle in flat footwear users is (Rt- 14.27 \pm 1.64$)$, (Lt-14.18 \pm 0.95$)$ in supine; (Rt15.15 \pm 2.22$)$, (Lt.15.18 \pm 1.89$)$ in standing. In wedged heel users is (Rt-16.39 \pm 1.58$),($ Lt-16.06 \pm 1.92$)$ in supine and in standing (Rt-16.82 \pm 2.07$)$, (Lt-16.58 \pm 1.95$)$ respectively. In pointed heel users is (Rt-18.76 \pm 1.5$),(\mathrm{Lt}-18.58 \pm 1.25)$ in supine; and (Rt-18.85 \pm 1.28$)$, (Lt-18.76 \pm 1.3$)$ in standing. There was statistically significant increase in participant's $Q$ angle $(p<0.0001)$ with change in type (surface area of contact) of footwear.

Conclusion: Variable heel type has an effect on $Q$ angle. The Flat heel users have normal $Q$ angle. Wedge heels and pointed heels are associated with significant increase in $Q$ angle.

Clinical implication: Usage of flat footwear is advisable for good lower limb mechanics. Wedges are not better than pointed heel footwear.

KEY WORDS: Q angle, Flat heel, Wedge heel, footwear.

Address for correspondence: Dr. Namrata Sidhaye- Bhadbhade (M.P.T), D.E.Society's Brijlal Jindal college of Physiotherapy, Fergusson college campus, Shivajinagar, Pune- 411004, Maharashtra, India.E-Mail: namratasidhaye.physio@gmail.com

Access this Article online

Quick Response code

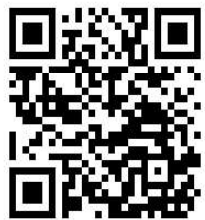

DOI: $10.16965 /$ ijpr.2020.164

Journal Information

International Journal of Physiotherapy and Research

ISSN (E) 2321-1822 | ISSN (P) 2321-8975

https://www.ijmhr.org/ijpr.html

DOI-Prefix: https://dx.doi.org/10.16965/ijpr

(c) $\overline{\mathrm{Er}-\mathrm{Mb}-\mathrm{si}}$

Article Information

Received: 05 Aug 2020

Peer Review: 06 Aug 2020

Revised: None
Accepted: 07 Sep 2020

Published (O): 11 Oct 2020

Published (P): 11 Oct 2020

\section{INTRODUCTION}

Women wear High-heel footwear to make themselves look taller and fashionable. The use of high heeled footwear is, and will always be, a common practice among women. According to survey (Farhat Sadique Basha, R. Gayatri Devi, A. Jothi Priya 2018), it has been revealed that
$80 \%$ of women wear high heel footwear, out of which $50 \%$ wear by preference and $30 \%$ women use because of their profession [1].

Some workplace studies showed that women who are working in the hospitality industry like hotel management, makeup artist, corporate sector, air hostess wear high heels regularly for 
long hours [1].

There are several types of footwear used by teenager women, which are variable in height and width of the heel and also in the inclination of the sole. The most commonly used heel types are flats, wedges, and pointed heels.

Flat footwear has heel height which is either equal or close to the height of the forefoot sole [2]. The wedge heel type allows the force applied by the heel on the sole of the shoe to cross evenly over a wide area on the ground, ensuring the balance of the user. Wedge heels are slightly narrower in the rear foot region when compared with the forefoot region; causing an inclination of the Tibiotarsal joint as sole of the forefoot is thin and of rear foot is thick and narrower $[2,3]$. The pointed heel footwear has thin sole at forefoot region and of rear foot is at some height as compared to forefoot.

The effects of the width and height of the heel of the shoe on the body have been revealed to exhibit differences in lower extremity mechanics and energy cost. Biomechanical and physiological studies show that the ground reaction force vector becomes more vertical which causes more strain on weight bearing joints and pressure on the forefoot during the use of high-heels $[4,5]$ as well as uneven distribution of weight on foot[6]. Other negative side effects also include increased risk of falling [7], stress fractures [8] and increased stress on other lower limb joints like Patellofemoral joint leading to pain [9].

Studies have reported that there are permanent changes associated with bone and muscle adaptions in those who use high heel footwear on daily basis, even after the removal $[10,11]$.

The measurement of the quadriceps angle (Q-angle) can be performed using different methods, such as the radiographic method or clinically with the goniometer [11]. It has been shown that increase in heel height causes various changes in individual's postures, and lower limb alignment. The angle reflects the effects of Quadriceps mechanism on the knee and depicts the overall alignment of the lower limb [11] as many studies have shown that alteration in position of one body segment affects the other segment of the body [12].
It is also a common belief that wedges are better than pointed heels. Hence there is need to find out if the heel type has any effect on lower limb alignment with constant heel height. There is dearth of literature about effect of change in surface area of contact on $Q$ angle. Hence present study was done to assess the $Q$ angle in women using flat heel footwear, wedged heel footwear and pointed heel footwear as well as to compare the $Q$ angle in these heel types. The height for wedged heel footwear and pointed heel footwear is kept constant i.e. $4 \mathrm{~cm}$.

\section{MATERIALS AND METHODS}

147 adult females were screened out of which 99 were selected according to inclusion and exclusion criteria. Inclusion criteria was women wearing heels for 6 hours per day for 6 months [13], Healthy women (fat percentage 15- 30\%, waist hip ratio is it the $\leq 0.85$ ) [14], Age 21 to 39 years. Exclusion criteria was women with congenital problems of spine and lower limb, any recent fracture or injury to lower limb or spine, women having limb length discrepancy.

All subjects participated voluntarily after being informed about the purpose of the study and having signed a written informed consent. Selected 99 women are divided in three groups $(n=33)$ namely: Flat heel users, Wedged heel footwear users with $4 \mathrm{~cm}$ heel height, Pointed heel footwear users with $4 \mathrm{~cm}$ heel height.

Demographic data (name, age, occupation, weight, height) of each subject was documented. Fat percentage was measured using Tanita: body composition analyser and waist and hip circumference were measured by tape in centimetres. The $Q$ angle measurements were taken in supine and standing by universal goniometer.

\section{$\mathbf{Q}$ angle measurement in supine position: Each} subject was asked to lie supine with completely relaxed quadriceps and hips in neutral rotation. After adequately exposing the subject, bony landmarks like ASIS, midpoint of patella and tibial tuberosity were marked by marker.

The first line joining the ASIS to midpoint of patella is drawn, similarly second line joining the tibial tuberosity and midpoint of patella is drawn as shown in Figure 1 .The angle of intersection of these two lines ( $Q$ angle) is measured 
with the Universal goniometer.

$Q$ angle measurement in standing position: Each subject was asked to stand in erect position by bearing equal weight on both lower limbs. After adequately exposing the subject, bony landmarks like ASIS, midpoint of patella and tibial tuberosity were marked by marker.

The first line joining the ASIS to midpoint of patella is drawn, similarly second line joining the tibial tuberosity and midpoint of patella is drawn as shown in Figure 2. The angle of intersection of these two lines ( $Q$ angle) is measured with the Universal goniometer.
$\mathrm{Q}$ angle measurement in each positions was taken twice and mean of the measurements was considered. In order to avoid manual error the bony landmark palpation and $Q$ angle measurements were practiced on 20 subjects under the supervision of experts.

The design of this study is cross sectional and observational. This study was conducted from June 2018 to Feb 2019.

Statistical analysis of the collected data was done by one way ANOVA and Post Hoc analysis. (SPSS software version: 17.0)

RESULTS

Table 1: Descriptive table

\begin{tabular}{|c|c|c|c|c|c|c|c|c|c|}
\hline Groups & $\mathrm{n}$ & & Age & Height & Weight & \multicolumn{2}{|c|}{ Fat $\%$} & $\mathrm{~W} / \mathrm{H}$ & BMI \\
\hline Flat heel footwear & 33 & \multicolumn{2}{|c|}{$21.39 \pm 0.86$} & $157 \pm 5.24$ & $54.09 \pm 5.43$ & \multicolumn{2}{|c|}{$30.11 \pm 4.02$} & $0.68 \pm 0.04$ & $22.35 \pm 2.58$ \\
\hline Wedged heel footwear & 33 & \multicolumn{2}{|c|}{$21.09 \pm 3.13$} & $154.5 \pm 5.47$ & $53.17 \pm 8.08$ & \multicolumn{2}{|c|}{$28.25 \pm 4.84$} & $0.68 \pm 0.05$ & $23.72 \pm 4.28$ \\
\hline Pointed heel footwear & 33 & \multicolumn{2}{|c|}{$22.27 \pm 2.89$} & $155 \pm 3.87$ & $51.34 \pm 6.89$ & \multicolumn{2}{|c|}{$28.31 \pm 5.48$} & $0.69 \pm 0.07$ & $21.61 \pm 2.5$ \\
\hline \multirow{6}{*}{$\begin{array}{l}\text { Table 2: } Q \text { angle measu } \\
\text { supine and standing }\end{array}$} & & & & \multicolumn{2}{|c|}{ Flat heel footwear } & \multicolumn{2}{|c|}{ Wedge heel footwear } & \multicolumn{2}{|c|}{ Pointed heel footwear } \\
\hline & & & & MEAN & SE & MEAN & SE & MEAN & \begin{tabular}{|l|l|} 
SE \\
\end{tabular} \\
\hline & & & $\begin{array}{l}\text { Supine } \\
\text { (Left knee) }\end{array}$ & $14.27 \pm 1.64$ & 0.29 & $16.06 \pm 1.92$ & 0.33 & $18.58 \pm 1.25$ & 0.22 \\
\hline & $\begin{array}{l}\text { eme } \\
\text { osit }\end{array}$ & in & $\begin{array}{c}\text { Supine } \\
\text { (Right knee) }\end{array}$ & $14.18 \pm 0.95$ & 0.17 & $16.39 \pm 1.58$ & 0.28 & $18.76 \pm 1.5$ & 0.26 \\
\hline & & & $\begin{array}{l}\text { Standing } \\
\text { (Left knee) }\end{array}$ & $15.15 \pm 2.22$ & 0.39 & $16.58 \pm 1.95$ & 0.34 & $18.76 \pm 1.3$ & 0.23 \\
\hline & & & $\begin{array}{c}\text { Standing (Right } \\
\text { knee) }\end{array}$ & $15.18 \pm 1.89$ & 0.33 & $16.82 \pm 2.07$ & 0.36 & $18.85 \pm 1.28$ & 0.22 \\
\hline
\end{tabular}

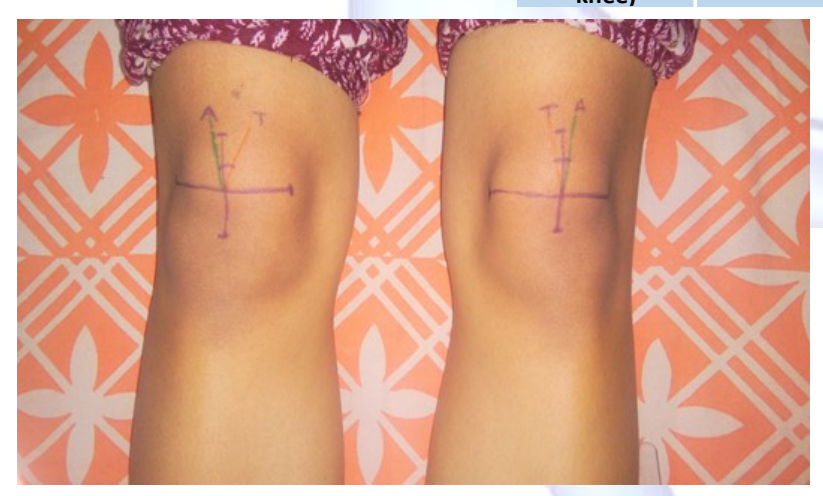

Fig. 1: $Q$ angle in Supine position

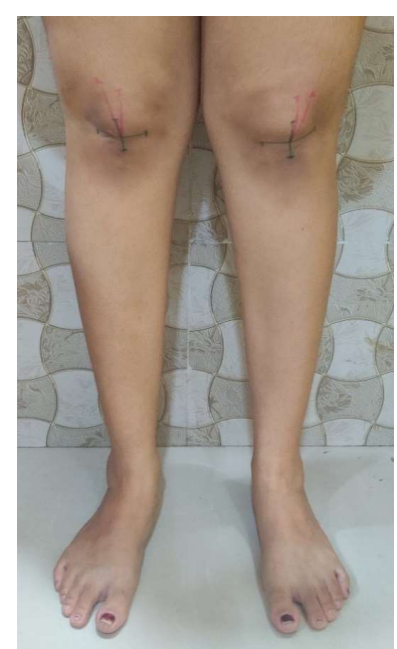

Fig. 2: $Q$ angle in standing position.
Graph 1: $Q$ angle measurement at Right knee in supine position.

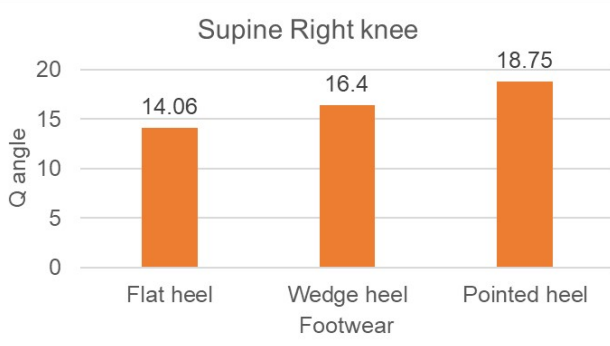

The graph shows that $Q$ angle is increasing at Right knee in supine position when footwear is changed. The difference is significant as $p<$ 0.0001 .

Graph 2: $Q$ angle measurement at Left knee joint in supine position.

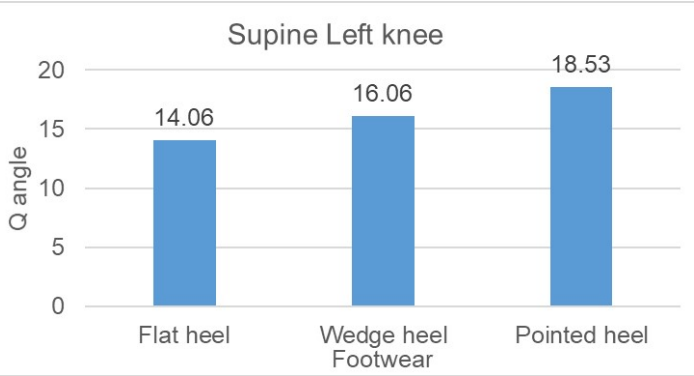

The graph shows that $Q$ angle is increasing at 
Left knee in supine position when footwear is changed. The difference is significant as $p<$ 0.0001 .

Graph 3: $Q$ angle measurement at Right knee joint in standing position.

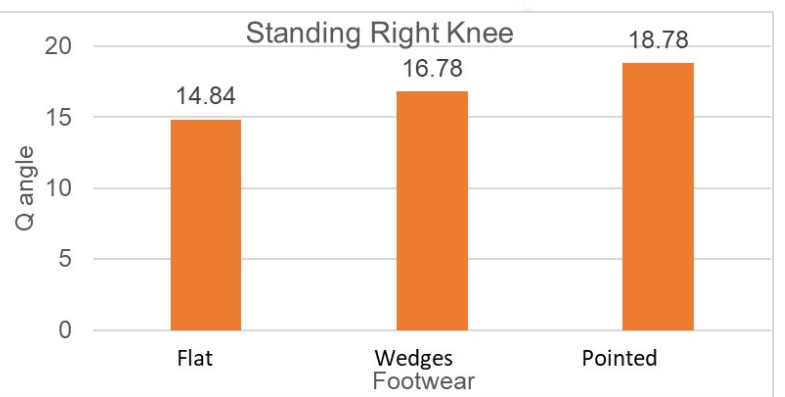

The graph shows that $Q$ angle is increasing at Right knee in standing position when footwear is changed. The difference is significant as $p<$ 0.0001 .

Graph 4: $Q$ angle measurement at left knee in standing position.

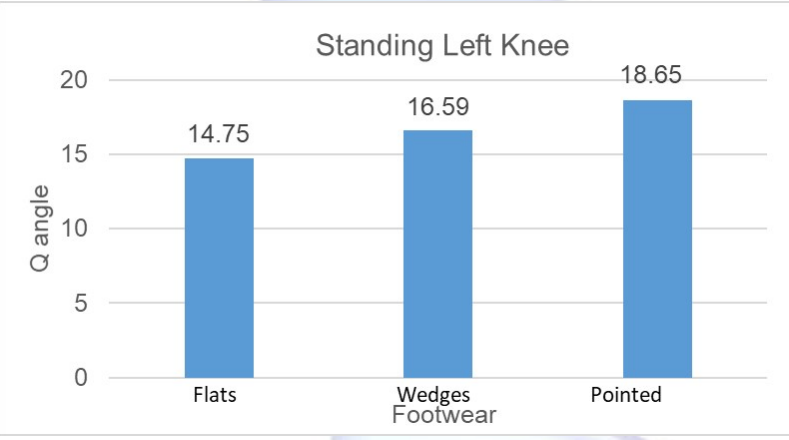

The graph shows that $Q$ angle is increasing at Left knee in standing position when footwear is changed. The difference is significant as $p<$ 0.0001 .

\section{DISCUSSION}

The present study showed that females using variable type of footwear like flats, wedges, and pointed heels on daily basis; there is significant change in $Q$ angle.

The surface goniometry protocol described in this study is appeared to be reliable for relatively lean young men and women. Hence inclusion criteria like BMI 18-25 [14], waist hip ratio is $\leq 0.85$ [14]. Body fat percentage 15-30 was considered, so that all the bony prominences are easily palpable in these individuals [11].

The heel height chosen for wedged heel and pointed heel is $4 \mathrm{~cm}$ because in studies it has been shown that heel height above $3 \mathrm{~cm}$ there are changes seen in EMG of Vastus Medialis and
Vastus Lateralis and muscle activation strategies around knee joint [15].

The $Q$ angle is taken in supine (non-weight bearing position) and standing position (weight bearing position and functional position) in order to check if the changes are permanent.

Footwear that has a heel size that is equal or close to the height of the forefoot sole does not cause horizontal imbalance of the sole and, therefore, will not affect the biomechanical alignment of the ankles; as in flat footwear. Wedge heels are slightly narrower in the rear foot region but are wide as compared to pointed heels to support base of the heel. In wedge and pointed heels footwear there is narrow base of support in the rare foot region compared to flat heels. This results in reduced area for pressure distribution on ground, which can alter the alignment of the lower limb [16].

Increase in $Q$ angle is attributed to reduction in surface area of contact. As the surface area of contact reduces the pressure per unit area increases. This also causes increase in focal force magnitude. Usage of high heels (wedges and pointed) results in elevation of the Calcaneum which is associated with the flexion at the Tibiotalar joint. This leads to elevation and forward displacement of the COG, causing postural imbalance, promoting adaptive postural adjustments for balance recovery and to maintain the upright posture [10]. It triggers several changes in posture, in the lower limbs and spine, like forward head posture, increased lordosis, valgus at knee, etc.

The plantar flexion at ankle causes rear foot supination. This results in excessvie activation of Tibialis Posterior (sling of MLA), leading to fatigue of Tibialis posterior, which causes loss of MLA (medial longitudinal arch). Hence Knee Valgus (increase in $Q$ angle) is seen. Increase in $Q$ angle causes increase in the magnitude of the above mentioned patho-biomechanical changes [15]. It is verified that with increase in $Q$ angle, increases the stress on the Patellofemoral joint due to more magnitude of the knee extensor moment, Simonsen et al demonstrated that it also intensifies the knee abduction moment [15].

There is no significant difference noted between 
left knee and right knee $Q$ angles of the subjects. There are evidences which showed that the individuals whose $Q$ angle is more than 20 degrees are symptomatic [17]. There were 3 subjects whose $Q$ angle was more than 20 degree and they were symptomatic; being duration for wearing high heels was more than 5 years.

In our study the heel height was kept constant 4 $\mathrm{cm}$ for wedge heel and pointed heel. $Q$ angle in wedge heel users is less as compared with pointed heel users, but significantly greater if compared with flat heel users.

Limitations: Less sample size was taken. Sampling method was convenient. Recreational activities of the subjects were not considered.

\section{CONCLUSION}

Variable heel type affects the $Q$ angle. The Flat heel users have normal $Q$ angle. Wedge heels and pointed heels are associated with significant increase in $Q$ angle

\section{CLINICAL IMPLICATION}

For maintenance of better lower limb alignment or body posture it is advised to wear flat foot wear. Wedged heel footwear is not better than pointed heel footwear. Prolonged use of wedge as well as pointed heel footwear leads to pathomechanical changes in the closed kinematic chain which can be permanent.

\section{ABBREVIATIONS}

BMI: Body mass Index,

W/H: Waist- hip ratio,

EMG: Electromyography,

SPSS: Statistical Package for the Social Science,

ANOVA: Analysis of Variance

\section{ACKNOWLEDGEMENTS}

I would like to express my deep gratitude towards my guide Dr. Namrata SidhyeBhadbhade for her patient guidance, her enthusiasm, encouragement and useful critics of this research work. I would also like to thank my teachers, Dr. Atiya shaikh and Dr. Aditi Berry for their valuable suggestions. I would like to thank Professor of Department of Research Methodology and Medical Statistics, Mr. Sagar Khandagale MSc (Statistics) for my all statistical calculations. I would also like to extend my thanks to my friends who have helped me in one or other way to complete my work. Finally I wish to thank my parents for their support throughout my study.

\section{Conflicts of interest: None}

\section{REFERENCES}

[1]. Farhat yaasmeen sadique basha, R, Gayatri Devi , A. Jothi Priya A survey on comparative effects of wearing high heels among long term and short term users. JPRS-Pcol-00002643

[2]. Silva AM, de Siqueira GR, da Silva GA. Implications of high-heeled shoes on body posture of adolescents. Rev Paul Pediatr. 2013;31(2):265-271. https:/ /doi.org/10.1590/S0103-05822013000200020 PMid:23828066

[3]. Carrasco AC. Estudo da distribuição da pressão plantar e da oscilação corporalem relação ao peso da bolsa e ao uso de salto alto em mulheres [tese demestrado]. São José dos Campos (SP): Universidade do Vale do Paraíba; 2010.

[4]. Ebbeling CJ, Hamill J, Crussemeyer JA. Lower extremity mechanics and energy cost of walking in high-heeled shoes. J Orthop Sports Phys Ther 1994; 19:190-6. https://doi.org/10.2519/jospt. 1994.19.4.190 PMid:8173565

[5]. Snow RE, Williams KR. High heeled shoes: Their effect on center of mass position, posture, threedimensional kinematics, rearfoot motion, and ground reaction forces. Arch Phys Med Rehabil 1994; 75:568-76.

[6]. Ko DY, Lee HS. The changes of COP and foot pressure after one hour's walking wearing high-heeled and flat shoes. J Phys Ther Sci 2013;25:1309-12.

https://doi.org/10.1589/jpts.25.1309 PMid:24259782 PMCid:PMC3820172

[7]. Tencer AF, Koepsell TD, Wolf ME, Frankenfeld CL, Buchner DM, Kukull WA, et al. Biomechanical properties of shoes and risk of falls in older adults. J Am Geriatr Soc 2004;52:1840-6.

https://doi.org/10.1111/j.1532-5415.2004.52507.x PMid:15507060

[8]. Keegan TH, Kelsey JL, King AC, Quesenberry CP Jr. Sidney S. Characteristics of fallers who fracture at the foot, distal forearm, proximal humerus, pelvis, and shaft of the tibia/fibula compared with fallers who do not fracture. Am J Epidemiol 2004;159: 192-203. https://doi.org/10.1093/aje/kwh026 PMid:14718222

[9]. Ho KY, Blanchette MG, Powers CM. The influence of heel height on patellofemoral joint kinetics during walking. Gait Posture 2012;36:271-5. https://doi.org/10.1016/j.gaitpost.2012.03.008 PMid:22520457

[10]. Pezzan, Patrícia A. O., Sacco, Isabel C. N., \& João, Silvia M. A. Postura do pé e classificação do arco plantar de adolescentes usuárias e não usuárias de calçados de salto alto. Brazilian Journal of Physi- 
-cal Therapy, 2009;13(5):398-404. https://doi.org/ 10.1590/S1413-35552009005000053

[11]. Weiss L, DeForest B, Hammond K, Schilling B, Ferreira L. Reliability of goniometry-based Q-angle. The American Academy of Physical Medicine and Rehabilitation. 2013;5(9):763-768.

https://doi.org/10.1016/j.pmrj.2013.03.023 PMid:23528815

[12].Jessica Shrestha, Biswabina Ray and Antony Sylvan D Souza. Representative values for lower extremity alignment measures in females. Int. J. of Adv. Res. 2016;4:754-759.

[13]. Elshamy, F.F., Ghait, A.S., \& Morsy, M. The effect of high heels on quadriceps angle in adult females. International Journal of Therapies and Rehabilitation Research, 2016;5:35-38. https://doi.org/10.5455/ijtrr.000000124

[14]. Section 6: Body Composition ACSM Guidelines: Chapter 4 (pp. 62 72) ACSM Manual: Chapters 4

[15]. Simonsen EB, Svendsen MB, Nørreslet A, et al. Walking on high heels changes muscle activity and the dynamics of human walking significantly. J Appl Biomech. 2012;28(1):20-28.

https://doi.org/10.1123/jab.28.1.20

PMid:22431211

[16]. Bendix T, Sorenson SS, Klausen K. Lumbar curve, trunk muscles, and line of gravity with different heel heights. Spine (Phila Pa 1976) 1984;9:223-7. https:/ /doi.org/10.1097/00007632-198403000-00016 PMid:6729584
[17]. Magee, David J. Orthopedic Physical Assessment. Saunders, From Knee. 4th edition . 2004;729-730.

[18]. Edwards L, Dixon J, Kent JR, Hodgson D, Whittaker VJ. Effect of shoe heel height on vastus medialis and vastus lateralis electromyographic activity during sit to stand. J Orthop Surg Res. 2008;3:2. https://doi.org/10.1186/1749-799X-3-2 PMid:18186937 PMCid:PMC2245915

[19].Hadeel ALSerhany, Fahad ALAnazi. Effect of prolonged wearing high heeled shoes on occurrence of low back pain (LBP) and disability among females in ALJouf city International Journal of Advanced Research 2015;3(12):1715-1722.

[20]. Elshamy, Fayiz F. et al. "The effect of high heels on quadriceps angle in adult females." International Journal of Therapies and Rehabilitation Research 2016;5:35-38.

https://doi.org/10.5455/ijtrr.000000124

[21]. Livingston LA. The quadriceps angle: a review of the literature. J Orthop Sports Phys Ther. 1998; 28(2):105-109.

https://doi.org/10.2519/jospt.1998.28.2.105 PMid:9699160

How to cite this article:

Pruthini Patil, Namrata Sidhaye- Bhadbhade. THE EFFECT OF HEEL TYPE

ON Q ANGLE. Int J Physiother Res 2020;8(5):3628-3633. DOI: 10.16965/ ijpr.2020.164 